\title{
Accounting Practices and Success of Business: A Survey of Traders of Muhanga Commercial Centre in Rwanda
}

\author{
Mrs. Uwamahoro Anastasie ${ }^{1 *}$, Dr. Claude Rusibana $(P h D)^{2}$ \\ *lEmail: uwamahoronasiri@gmail.com
}

\section{*Corresponding Author}

Email: uwamahoronasiri@gmail.com

\begin{abstract}
: -
Some businesses start well and whereas some succeed others fail. The question is why some businesses survive while others collapse. This study, therefore, seeks to inform traders and other profit oriented activities owners of Muhanga Commercial Centre about the role of accounting system in preparing and keeping the books of accounts and the relationship between accounting system and business success or performance. The specific objectives of the study are to find out whether traders of Muhanga commercial centre keep accounting records, to establish the factors affecting growth of business, to find out the performance level of the traders in Muhanga Commercial Centre and establish the relationship between accounting practices and success of the traders. This research is of significance to business managers and scholars. Considering the methodology used in this study, a descriptive survey research design was employed in this study in order to capture the general overview giving some valuable pointers as to what variables are worth testing quantitatively and can yield rich data that lead to important recommendations in practice. The target population for this study is 292 traders of Muhanga Commercial Center and the sample size of 74 respondents. Stratified sampling was used to select the sample respondents. Sample size was determined using Slovin's formula with $10 \%$ error margin. The qualitative and quantitative data was used. For primary data, questionnaires were sent to the respondents and interview was used. The secondary data was collected from journal articles, books and internet resources. Statistical Package for Social Sciences (SPSS) version 21.0 was used to analyse the relationship between accounting record keeping and the business success. Reliability of the instruments was established after a pre-test in order to establish the fitness of the instruments in the study. Moreover, experts in the field were consulted about the content of instruments, ambiguity of question items and their relevance. The results of the study revealed that there is a positive correlation between recording and business expansion with $p$-value of 0.912 and sig=.000; between financial statements and increase in asset with p-value of 0.780 and sig=.000; between reconciliation and increase in profit with a p-value of 0.884 and sig=.000; between reconciliation and financial statements with $p$-value of 0.674 and sig=.000; between increase in profit and recording with a p-value of 0.822 and sig=.000; between recording and financial statements with $p$-value of 0.615 and sig=.000; between reconciliation and recording with a p-value of 0.914 and sig=.000; between reconciliation and business expansion with a p-value 0.938 and sig=.000; increase in asset and business expansion with a p-value of .849 and sig=.000, increase in profit and business expansion with a p-value of 0.917 and sig=.000 and between financial statement and increase in profit with a $p-v a l u e$ of 0.802 and sig=.000 because the calculated P-value is less than 0.01 level of significance.
\end{abstract}

Keywords: - Accounting practices, business, business success and book keeping

\section{(a) $(\$)$}




\section{Background to the Study}

Success in business rests on good record keeping practices and solid cash flow (Ronney, 2008). Some businesses start well and end by failing; others start well and continue to exist and grow until they achieve a high level (Parker, 2002). The question can be why some survive and others collapse. The reasons should be many. However, this research is interested in one which is the accounting practices to the success of the business where the relationship between accounting practices and business success must be shown

Without good records it is impossible to determine the financial position or profitability of a business (LEO, 2010). As a business owner, one should be familiar with and recognize the importance of proper records keeping requirements and cash-flow planning (Saffady, 2000). When setting up a company, regardless of the size, there are requirements under the Companies Act regarding the maintenance of books and records (LEO, 2010). As a business person it is important that one is aware of the legal requirements, and ensure that he or she is able to produce the required information (Reynolds, 2010).

Record keeping refers to day-to-day maintenance of business transactions and accurate manipulating them to produce accurate and consistent financial statements (Parker, 2002). Record keeping is the process of keeping full, accurate, up to date business records (Reynolds, 2010). Complete and accurate financial record keeping will be crucial to one's business for the following reasons providing financial data that help to operate more efficiently, thus increasing one's profitability and identifying all business assets, liabilities, income and expenses (Reynolds, 2010).

Good records are essential for the preparation of business end year returns and financial statements (LEO, 2010). This is because these statements are very important not only for your business but also for the various stakeholders like revenue authority and banks amongst others. The necessity of recording all the transactions clearly and systematically cannot be over-emphasized (Mairura, 2011). Goods may be sold on credit to several persons. The latter would pay the price of the goods to vendor later. However strong one's memory may be, one cannot hope to remember all the details regarding the transactions (Mairura, 2011). According to Mayinja (2007), accounting records have been cited as one of the possible factors contributing to success of business.

According to Hughes (2003), keeping records is crucial for the successful performance of a business. A comprehensive record keeping system makes it possible for entrepreneurs to develop accurate and timely financial reports that show the progress and current condition of the business (Rahamon, 2014). With the financial report, one can generate from a good record keeping system, compare performance during one period of time (month, quarter or year) with another period, calculate trends and plan for the business future (Samuel, 2019, and Adekunle, 2018). Financial analysis is the most important element in management activities of all kinds of institutions; profit oriented, non- profit oriented and public institutions (Kabera, 2009). Financial reporting is not the end in itself but it is intended to provide information that is useful in making business and economic decisions (Financial Accounting Standards Board, 2008). In this regard, the researcher is motivated by finding the extent to which management dealers may depend on accounting information in decision making which leads to the success of the business. Financial analysis, also called financial statements or accounting analysis refers to an assessment of the viability, stability and profitability of a business (Balachandran et al., 2014). It is performed by professionals who prepare report using accounting information, and who make use of information taken from financial statements and other reports. These reports are usually presented to the top management as one of their bases in making business decisions (Elliott, 2009).

Financial analysis and accounting information are the aspects of overall business financial function that involves examining historical data to gain information about the current and future financial health of a company or a business (Ronney, 2008). It is evident that good record keeping system is important and geared to enhancing the business performance; survey shows that most businesses are often strongly based on the owner-manager's know- how and expertise as evidenced in their company. A common assumption is that the owner- managers have sufficient technical knowledge but they lack managerial skills or sophisticated managerial practices (Maes, et al., 2004). Kwabena (2013) argues that the firms are more likely to engage in informal management practices than to adopt sophisticated planning and control techniques. The researcher in this particular study wishes to evaluate the relationship between accounting record keeping practices and success of the businesses

\section{Research objectives 2.1.General objective}

The general objective of this study is to establish the relationship between accounting system and success of the business among traders of Muhanga Commercial Centre, Rwanda.

\subsection{Specific Objectives}

The specific objectives of the study are as follows:

(i) To find out whether the traders of Muhanga Commercial Centre prepare and keep accounting records;

(ii) To find out the financial performance level of traders of Muhanga Commercial Centre;

(iii) To establish the relationship between accounting practices and success of the traders of Muhanga Commercial Centre.

\section{Methodology}

Descriptive survey research design was employed in this study. As such, descriptive statistics instruments such as tables of frequency and percentage distribution were used to describe the profile of respondents, while means and measures of variation were applied to examine whether the traders of Muhanga Commercial Centre prepare and keep accounting records and to examine their financial performance level. According Schuman (2004), descriptive research designs help 
provide answers to the questions of who, what, when, where, and how associated with a particular research problem; descriptive research is used to obtain information concerning the current status of the phenomena and to describe what exists with respect to variables or conditions in a situation.

According to Schuman (2004) the target population means all members of a specified group to which the study relates. In the perspective of this research project, the target population is comprised of 292 traders of Muhanga Commercial Centre as revealed by Ministry of Industry and Commerce (MINICOM) in 2010. From the population of 292 traders of Muhanga Commercial Centre, the sample size of 74 traders was selected using Sloven's formula to determine sample size and stratified random sampling technique were used.

\section{Research Findings}

This section identifies and exploded the research findings through questionnaire and interviews of respondents in relation to study objectives

\subsection{The traders of Muhanga Commercial Centre prepare and keep accounting records}

In this sub-section, the researcher presents, analyses and interprets the respondents"

Table4.1: Accounting Records Preparing and Keeping

\begin{tabular}{|c|c|c|c|}
\hline Statement regarding accounting records preparing and keeping & YES (N/\%) & No $(\mathrm{N} / \%)$ & $\mathrm{N} / \%(74 / 100)$ \\
\hline Business prepares records (cash receipts, sales, purchases and debtors) & $70(94.6)$ & $4(5.4)$ & $74(100.0)$ \\
\hline Business produces the financial statement from the records made & $72(97.3)$ & $2(2.7)$ & $74(100.0)$ \\
\hline Business keeps accounting records and financial statement prepared & $70(94.6)$ & $4(5.4)$ & $74(100.0)$ \\
\hline Business owners are responsible for records keeping & $70(94.6)$ & $4(5.4)$ & $74(100.0)$ \\
\hline Business does both manual and computerized accounting & $70(94.6)$ & $4(5.4)$ & $74(100.0)$ \\
\hline Business uses computerized accounting & $73(98.6)$ & $1(1.4)$ & $74(100.0)$ \\
\hline Proper procedures are followed to prepare and keep the accounting records & $69(93.6)$ & $5(6.4)$ & $74(100.0)$ \\
\hline Accounting records require skilled personnel and a lot time & $73(98.6)$ & $1(1.4)$ & $74(100.0)$ \\
\hline
\end{tabular}

Source: Primary Data, 2019

perceptions about whether the traders of Muhanga Commercial Center prepare and keep accounting records. The findings in Table 4.1 indicates that $73(98.6 \%)$ of respondents asserted that business uses computerized accounting, 73 (98.6) of respondents asserted accounting records require skilled personnel and time, $72(97.3 \%)$ of respondents asserted that business produces financial statement from the records made, $71(95.9 \%)$ of respondents produce financial statements from records made in their business, 70 (94.6\%) asserted that business prepares records such receipts, purchase creditors and debtors ledgers in their business in Muhanga Trading Center, the accounting records,

Table 4. 2: Financial Performance Level of Muhanga Traders

\begin{tabular}{|c|c|c|c|}
\hline Statement regarding financial performance level of Muhanga Traders & YES (N/\%) & No $(\mathbf{N} / \%)$ & $N / \%(74 / 100)$ \\
\hline Business increased profitability level for the last five years & 73 (98.6) & $1(1.4)$ & $74(100.0)$ \\
\hline Below 20\% & $44(59.5)$ & & \\
\hline Between 20 and $40 \%$ & $20(27.1)$ & & \\
\hline Above $40 \%$ & $5(6.8)$ & & \\
\hline I am not sure & $5(6.8)$ & & \\
\hline Business increase the level of financial assets for the last five years & $71(95.9)$ & $3(4.1)$ & $74(100.0)$ \\
\hline Below $20 \%$ & $47(63.5)$ & & \\
\hline Between 20 and $40 \%$ & $13(17.6)$ & & \\
\hline Above $40 \%$ & $8(10.8)$ & & \\
\hline I am not sure & $6(8.1)$ & & \\
\hline Business increase the level of sales for the last five years & $72(97.3)$ & $2(2.7)$ & $74(100.0)$ \\
\hline Below $20 \%$ & $57(77.0)$ & & \\
\hline Between 20 and $40 \%$ & $11(14.9)$ & & \\
\hline Above $40 \%$ & $4(5.4)$ & & \\
\hline I am not sure & $2(2.7)$ & & \\
\hline
\end{tabular}

Source: Primary Data, 2019

$70(94.6 \%)$ of respondents asserted that bussiness keeps accounting records and financial statements prepared, 70 (94.6\%) of the total respondents agreed that Business owners being responsible for record keeping, 70 (94.6\%) of the total respondents agreed that business does both manual and computerized accounting and 69 (93.6\%) of the total 
respondents agreed that proper procedures are followed to prepare and keep the accounting records. Thus, implies that Muhanga Traders does accounting records preparation and keeping to enhance business sucess in Muhanga Trading Center, Rwanda.

Table 4. 3: Accounting practices and success of traders

\begin{tabular}{|c|c|c|c|c|c|}
\hline Statement regarding accounting practices and success of traders & $\mathrm{SD} / \%$ & $\mathrm{D} / \%$ & $\mathbf{N} / \%$ & $\mathbf{A} / \%$ & $\mathbf{S A} / \%$ \\
\hline Accounting sys & $(4.1)$ & $(1.4)$ & $(4.1)$ & $(4.1)$ & $64(86.5)$ \\
\hline Accounting and recordkeeping practices are essential for decision making & $(2.7)$ & $(1.4)$ & $(1.4)$ & $(5.4)$ & $66(89.2)$ \\
\hline Accounting records are essential for preparation of financial statements & $(2.7)$ & 4) & $(1.4)$ & $(4.1)$ & 67 \\
\hline Records preparing and keeping helps to increase sales volume and profitability & $(2.7)$ & $(1.4)$ & $(1.4)$ & $(5.4)$ & $66(89.2)$ \\
\hline Records preparing and keeping improves efficiency and productivity & $(4.1)$ & $(1.4)$ & $(5.4)$ & $(6.8)$ & $61(82.4)$ \\
\hline Accounting records assist in resources allocation and expansion of activities & $(4.1)$ & $(1.4)$ & $(2.7)$ & $(6.8)$ & $63(85.1)$ \\
\hline Accounting records helps to manage for and increase the business assets & $(2.7)$ & $(1.4)$ & $(4.1)$ & $(5.4)$ & $64(86.5)$ \\
\hline Financial records preparing and keeping contribute to the business success & $(4.1)$ & $(1.4)$ & $(4.1)$ & $(4.1)$ & $64(86.5)$ \\
\hline Preparation of financial statements contribute to the business success & $(4.1)$ & $(1.4)$ & $(4.1)$ & $(4.1)$ & $64(86.5)$ \\
\hline Accounting records support business audit and research & $(2.7)$ & $(1.4)$ & $(1.4)$ & $(5.4)$ & $67(90.5)$ \\
\hline
\end{tabular}

Source: Primary Data, 2019

The results in table 4.2 indicates that $73(98.6 \%)$ of business incurred business profitability increment whereby a big number of their increment is below $20 \%$ at rate of $44(59.4 \%), 71(95.8 \%)$ of business incurred increment of financial assets whereby a big number of their increment is below $20 \%$ at rate of $47(63.5 \%)$, and 72 (97.3) of business

The results in table 4.3 indicates that $67(90.5 \%)$ of respondents strongly agreed that accounting records support business audit and research, $67(90.5 \%)$ of respondents strongly agreed that accounting records are essential for preparation of financial statements, 64 (86.5) of respondents strongly agreed that accounting records helps to manage for and increase the business assets, $63(85.1 \%)$ of respondents strongly agreed that accounting records assist in resources allocation and expansion of activities.

Incurred sales increment whereby a big number of their increment is below $20 \%$ at rate of 57 (77.0\%). Thus, implies that most of the Muhanga Commercial Trading business owners have incurred financial performance as an indicator of their business success.

$66(89.2 \%)$ of respondents strongly agreed that accounting and recordkeeping practices are essential for decision making, $66(89.2 \%)$ of respondents strong agreed that records preparing and keeping helps to increase sales volume and profitability, $64(86.5 \%)$ of respondents strongly agreed that preparation of financial statement contribute to business success, and $61(82.4 \%)$ of respondents strongly agreed that records preparing and keeping improves efficiency and productivity. Thus, that shows that accounting practices affect business success in Muhanga Trading Center, Rwanda.

Table 4.4: Correlation analysis between accounting practices and business success

\begin{tabular}{|c|c|c|c|c|c|c|c|}
\hline & & Record & $\begin{array}{l}\text { Financial } \\
\text { Statements }\end{array}$ & Reconciliations & $\begin{array}{l}\text { Increase } \\
\text { Profit }\end{array}$ & $\begin{array}{c}\text { inIncrease } \\
\text { Asset }\end{array}$ & $\begin{array}{r}\text { in Business } \\
\text { expansion }\end{array}$ \\
\hline \multirow{3}{*}{ Recording } & Pearson Correlation & 1 & $.615^{* *}$ & $.914^{* *}$ & $.822^{* *}$ & $.780^{* *}$ & $.912^{* *}$ \\
\hline & Sig. (2-tailed) & & .000 & .000 & .000 & .000 & .000 \\
\hline & $\mathrm{N}$ & 74 & 74 & 74 & 74 & 74 & 74 \\
\hline \multirow{3}{*}{$\begin{array}{l}\text { Financial } \\
\text { Statements }\end{array}$} & Pearson Correlation & $.615^{* *}$ & 1 & $.674^{* *}$ & $.802^{* *}$ & $.794^{* *}$ & $.724^{* *}$ \\
\hline & Sig. (2-tailed) & .000 & & .000 & .000 & .000 & .000 \\
\hline & $\mathrm{N}$ & 74 & 74 & 74 & 74 & 74 & 74 \\
\hline \multirow{3}{*}{$\begin{array}{l}\text { Reconciliat } \\
\text { ions }\end{array}$} & Pearson Correlation & $.914^{* *}$ & $.674^{* *}$ & 1 & $.884^{* *}$ & $.891^{* *}$ & $.938^{* *}$ \\
\hline & Sig. (2-tailed) & .000 & .000 & & .000 & .000 & .000 \\
\hline & $\mathrm{N}$ & 74 & 74 & 74 & 74 & 74 & 74 \\
\hline \multirow{3}{*}{$\begin{array}{l}\text { Increase in } \\
\text { Profit }\end{array}$} & Pearson Correlation & $.822^{* *}$ & $.802^{* *}$ & $.884^{* *}$ & 1 & $.946^{* *}$ & $.917^{* *}$ \\
\hline & Sig. (2-tailed) & .000 & .000 & .000 & & .000 & .000 \\
\hline & $\mathrm{N}$ & 74 & 74 & 74 & 74 & 74 & 74 \\
\hline \multirow{3}{*}{$\begin{array}{l}\text { Increase in } \\
\text { Asset }\end{array}$} & Pearson Correlation & $.780^{* *}$ & $.794^{* *}$ & $.891^{* *}$ & $.946^{* *}$ & 1 & $.849^{* *}$ \\
\hline & Sig. (2-tailed) & .000 & .000 & .000 & .000 & & .000 \\
\hline & $\mathrm{N}$ & 74 & 74 & 74 & 74 & 74 & 74 \\
\hline \multirow{3}{*}{$\begin{array}{l}\text { Expansion } \\
\text { of Business }\end{array}$} & Pearson Correlation & $.912^{* *}$ & $.724^{* *}$ & $.938^{* *}$ & $.917^{* *}$ & $.849^{* *}$ & 1 \\
\hline & Sig. (2-tailed) & .000 & .000 & .000 & .000 & .000 & \\
\hline & $\mathrm{N}$ & 74 & 74 & 74 & 74 & 74 & 74 \\
\hline
\end{tabular}

Source: Primary Data, 2019

The findings in Table 4.4 proves that there is a positive correlation between recording and business expansion $(\mathrm{p}=.912$ and sig=.000); between financial statements and increase in asset $(\mathrm{p}=.780$ and sig=.000); between reconciliation and increase in profit $(\mathrm{p}=.884$ and $\mathrm{sig}=.000)$; between reconciliation and financial statements $(\mathrm{p}=.674$ and $\mathrm{sig}=.000)$; 
between increase in profit and recording ( $\mathrm{p}=.822$ and sig=.000); between recording and financial statements $(\mathrm{p}=.615$ and sig=.000); between reconciliation and recording ( $\mathrm{p}=.914$ and sig=.000); between reconciliation and business expansion ( $\mathrm{p}=.938$ and $\mathrm{sig}=.000)$; increase in asset and business expansion $(\mathrm{p}=.849$ and sig=.000), increase in profit and business expansion ( $\mathrm{p}=.917$ and $\mathrm{sig}=.000)$ and between financial statement and increase in profit $(\mathrm{p}=.802$ and sig=.000) because the calculated P-value is less than 0.01 level of significance. Hence, there is a strong positive and significant relationship between $(\mathrm{p}=.849$ and $\mathrm{sig}=.000)$, increase in profit and business expansion $(\mathrm{p}=.917$ and $\mathrm{sig}=.000)$ and between financial statement and increase in profit $(\mathrm{p}=.802$ and $\mathrm{sig}=.000)$ because the calculated $\mathrm{P}$-value is less than 0.01 level of significance.

\section{Conclusion}

The findings on how accounting practices influences business success shows that a high percentage of business owners consider accounting practices such as recording, reconciliations, financial statement whereby business success is influenced through increase in profit, increase in asset and business expansion. Beal and Delpachitra (2003) argued that having accounting practices like recording, reconciliation and financial statement enables business owners and local investors to succeed in their business in terms of business expansion, increase in profit and increase in asset.

In addition, Rooij, et al. (2007) found that accounting practices affects business expansion because individuals with improved skills in recording are more likely to rely on other people as their main source of accounting practices and are less likely to make clear and successful business. Therefore, to increase the profit of a business, business owners need to use effective accounting practices. In conclusion all predictors of accounting practices including recording, financial statements, and reconciliation studied in this study are positively significant correlated to measures of business success include increase in profit, increase in asset and business expansion.

Hence, there is a positive correlation between recording and business expansion $(\mathrm{p}=.912$ and sig=.000); between financial statements and increase in asset $(\mathrm{p}=.780$ and sig=.000); between reconciliation and increase in profit ( $\mathrm{p}=.884$ and sig=.000); between reconciliation and financial statements $(\mathrm{p}=.674$ and sig=.000); between increase in profit and recording $(\mathrm{p}=.822$ and $\mathrm{sig}=.000)$; between recording and financial statements ( $\mathrm{p}=.615$ and sig=.000); between reconciliation and recording $(\mathrm{p}=.914$ and $\mathrm{sig}=.000)$; between reconciliation and business expansion $(\mathrm{p}=.938$ and sig=.000); increase in asset and business expansion

\section{Recommendations}

\subsubsection{Recommendations to Business Owners and Companies}

The findings of the study show that acceptability and usage of accounting practices in promoting business success. Accounting practices are used in all business and companies, so government together with private sector should encourage and teach business owners and companies on how to use accounting practices to ensure success of the business and hence economic development of the whole nation, business owners should be able to take better decision when investing their man and keeping records of all the finances spent in the business.

\subsubsection{Recommendation to Government}

The researcher would like to recommend to the government to build capacity and empower local business owners, investors and equip them with relevant knowledge and skills mostly in using accounting practices and other tips to ensure business success so that local investors and private sector should also participate in the policies formulated for them especially taxation and fiscal policies to enhance development of the country from the grassroots level. The government should work hand in hand with local and international investors to ensure that accounting practices are applied in all business in the country in order to help tax collector and auditor to have information to base on in case of audits hence economic development of the country due to success business as encouraged by accounting practices application.

\subsubsection{Recommendation to Investors and Private Sector}

The researcher would like to recommend seminars, study tours and workshops to local business owners, investors and Private Sector to enhance their knowledge and skills on the use of accounting practices in order to ensure the success of the business to increase the number of skilled and knowledgeable taxpayers to boost the economic development of the country.

\section{Reference}

[1].Adekunle, O. O. (2018). Record Keeping: A Strategy for Survival and Growth of Small and Medium Enterprises (SMES) Globally. During the Global SMES Summit held at NECA House, Central Business District, Alausa, Ikeja.

[2].Balachandran, B., Arumugam, A. \& Senthilkumar, A. (2014). Financial Analysis of "Corporation Bank" with Special Reference to Coimbatore, Tamilnadu. Research Journal of Finance and Accounting, 5(19), 92-99.

[3].Elliott, B. (2009). Financial Accounting and Reporting (13th ed.). Harlow: Financial Times Prentice Hall.

[4].Financial Accounting Standards Board (2008). Original pronouncements as amended. Statement of financial accounting concepts. Objectives of Financial Reporting by Business Enterprises.

[5].Hughes, C. (2003). Opportunities for Records Managers Working in the Private Sector: Records management society of Great Britain. Record Management Journal, 13(3), 117- 122.

[6].Kabera, L. (2009). The use of accounting ratios in decision making, Memoire online.

[7].Available at: https://www.memoireonline.com/12/09/3058/m_The-use-of-accounting- ratios-in-decision- 
making 1.html

[8].LEO (2010) Accounting Information Systems. Harlow: Financial Times Prentice Hall, New York. USA.

[9].Maes, J., Sels, L., \& Roodhooft, F. (2004). Learning about Small Business Profitability: The influence of management producer and owner Manager human capital. International Journal of Accounting Information systems, 6(12), 142-144.

[10]. Mairura, C.J. (2011). The Influence of Business records on Business Performance, Journal of Language, Technology \& Entrepreneurship in Africa, (3) 1,133-144.

[11]. Mayinja, M. (2007). Entrepreneurship education. Journal of language and entrepreneurship in Africa, 8(3), 203205.

[12]. Parker, S. (2002). Strategic Management Techniques for Record Managers. Record Management Bulletin, 109, $17-21$.

[13]. Reynolds, S. (2010). Importance of Recording Keeping. Managing imports and exports, 20, 9-10.

[14]. Romney, M. B. (2008). Accounting Information Systems (11th ed.). Harlow: Financial Times Prentice Hall.

[15]. Saffady, W. (2000). Knowledge Management: An Overview. The information management Journal, 11(7), 34, 3638.

[16]. Samuel, H.G (2019). Health policy effective record keeping and maternal mortality in Rwanda. Kigali, Rwanda.

[17]. Schuman, J. (1974). Educational Research: Competencies for Analysis and Application.

[18]. Raton: Scientific Publishers Stiansen. 